\title{
Utilization of agroindustrial byproducts for the production of lipase by a new strain of Pseudomonas sp.
}

\section{Utilização de subprodutos agroindustriais para a produção de lipase por uma nova cepa de Pseudomonas sp.}

\author{
Cristiani Baldo ${ }^{1}$, Lillian Maria Baggio ${ }^{2}$, Marcos Roberto Oliveira ${ }^{3}$, \\ Marcelo Rodrigues Melo ${ }^{4}$, Fabiana Guillen Moreira Gasparin ${ }^{5}$, \\ Maria Antonia Pedrine Colabone Celligoi ${ }^{6}$
}

\begin{abstract}
This study aimed to evaluate the production of lipases by a new strain of Pseudomonas sp. using fermentation medium containing byproducts of poultry meat or soybean oil industry. The results indicate that chicken fat and soybean gum induced $48.3 \mathrm{U} / \mathrm{mL}$ and 93.3 of lipase activity, respectively. However, the higher lipase production was obtained when the crude lecithin gum was used, archiving $272.6 \mathrm{U} / \mathrm{ml}$ of activity after 24 hours. The partial biochemical characterization of the enzyme showed that the optimum reaction conditions were $\mathrm{pH} 9.0$ and $35^{\circ} \mathrm{C}$. The enzyme was stable at temperatures between 25 to $75^{\circ} \mathrm{C}$ and at $\mathrm{pH}$ from 6 to 9 . The enzyme also showed good stability in organic solvents, such as acetronitrile, hexane, ethanol and isopropanol. This study indicates that the byproducts tested are promising for the production of lipase and can contribute to the reduction of enzymatic production costs on a large scale, increase the value of these byproducts and reduce potential environmental impacts caused by its accumulation in nature.
\end{abstract}

Keywords: Crude lecithin gum. Chicken fat. Enzyme. Fermentation.

\footnotetext{
${ }^{1}$ Doutorado pelo Programa de Pós-graduação Interunidades em Biotecnologia da Universidade de São Paulo (USP) / Instituto Butantan (IBu), São Paulo, São Paulo, Brasil. Professora do Departamento de Bioquímica e Biotecnologia da Universidade Estadual de Londrina (UEL), Londrina, Paraná, Brasil. E-mail: cristianibaldo@uel.br

${ }^{2}$ Graduação em Farmácia pela Universidade Estadual de Londrina, Londrina, Paraná, Brasil.

${ }^{3}$ Doutorado em Biotecnologia pela Universidade Estadual de Londrina, Londrina, Paraná, Brasil.

${ }^{4}$ Doutorado pelo Programa de Pós-graduação em Microbiologia Agrícola da Universidade Federal de Viçosa (UFV), Viçosa, Minas Gerais, Brasil. Professor Adjunto do Departamento de Bioquímica e Biotecnologia da Universidade Estadual de Londrina, Londrina, Paraná, Brasil.

${ }^{5}$ Doutorado em Ciências Biológicas (Biologia Celular) pela Universidade Estadual de Maringá (UEM), Maringá, Paraná, Brasil. Professora Adjunta C do Departamento de Bioquímica e Biotecnologia da Universidade Estadual de Londrina, Londrina, Paraná, Brasil.

${ }^{6}$ Doutorado em Ciências Biológicas (Microbiologia Aplicada) pela Universidade Estadual Paulista Júlio de Mesquita Filho (Unesp), Rio Claro, São Paulo, Brasil. Professora Associada C do Departamento de Bioquímica e Biotecnologia da Universidade Estadual de Londrina, Londrina, Paraná, Brasil.
} 


\section{Resumo}

Este estudo teve como objetivo avaliar a produção de lipases por uma nova cepa de Pseudomonas sp. utilizando meio de fermentação contendo subprodutos de industrialização de carne de frango e óleo de soja. Os resultados indicaram que a gordura de frango e a goma de soja induziram 48,3 $\mathrm{U} / \mathrm{mL}$ e 93,3 U/ml de atividade lipásica, respectivamente. No entanto, a produção de lipase mais elevada foi obtida quando a goma de lecitina bruta foi utilizada, induzindo $272,6 \mathrm{U} / \mathrm{ml}$ de atividade após 24 horas. A caracterização bioquímica parcial da enzima mostrou que as condições de reação ótimas foram de $\mathrm{pH} 9,0$ e $35^{\circ} \mathrm{C}$. A enzima foi estável nas temperaturas entre 25 a $75{ }^{\circ} \mathrm{C}$ e pH de 6 a 9. A enzima mostrou boa estabilidade em solventes orgânicos, tais como acetonitrila, hexano, etanol e isopropanol. Este estudo indicou que os subprodutos testados são promissores para a produção de lipase e podem contribuir para a redução dos custos de produção enzimática em larga escala, aumentar o valor desses subprodutos e reduzir potenciais impactos ambientais causados por sua acumulação na natureza.

Palavras-chave: Goma de lecitina bruta. Gordura de frango. Enzima. Fermentação.

\section{Introduction}

The utilization of enzymes in industrial processes arouses great interest due to the ease of obtaining and advantages in relation to chemical catalysts. The enzymatic catalysis allowing the increase of the products quality, reduction of production costs and less environmental impact. Consequently, the enzyme industry has progressively grown. The global market for industrial enzymes was estimated as $\$ 4.2$ billion and is expected to growth $7 \%$ until 2020 . Lipases are enzymes which have significant biological and industrial importance and ranks among the most currently commercialized enzymes after proteases and carboxylases. ${ }^{(1)}$

Lipases (triacylglycerol ester hydrolase, EC 3.1.1.3) are enzymes that catalyze the total or partial hydrolysis of fats and oils, releasing free fatty acids, diacylglycerols, monoacylglycerols, and glycerol. ${ }^{(2-4)}$ Lipases are ubiquitous in nature and are produced by plants, animals and microorganisms. ${ }^{(5)}$ However, microbial lipases, native or recombinant, are the most used in different biotechnological applications. ${ }^{(6)}$ The great industrial potential of microbial enzymes is due to their stability and variety of catalytic activity when compared to lipases of plant and animal origin. In addition, microorganisms can grow rapidly on inexpensive media and their growth are not affected by seasonal fluctuations.

The production costs are a major obstacle to the industrial application of lipases. An alternative for decreasing the production costs is the use of substrates such as industrial waste or byproducts. ${ }^{(7)}$ Therefore, it is important to point out that the industry dispense tons of waste that apparently has no function. However, this waste or byproducts are rich in nutrients as proteins, carbohydrates, lipids and minerals salts that can easily metabolized by microbial strains. ${ }^{(8)}$

In this study, we reported the production of a lipase by a new strain of Pseudomonas sp. in medium containing residual chicken fat and soybean oil residues as the only carbon source. The results showed that byproducts were very effective in the production of lipase by Pseudomonas sp and could contribute to the reduction of the production costs of this enzyme.

\section{Materials and Methods}

\section{Microorganism}

The strain named Pseudomonas sp. BF-6 were isolated from slaughter poultry effluent located in Londrina, PR, Brazil, using the minimum solid medium containing (g/L): $\mathrm{NaNO}_{3}$ (4), 
$\mathrm{KH}_{2} \mathrm{PO}_{4},(1.5), \mathrm{FeCl}_{3}(0.05), \mathrm{MgSO}_{4}(0.2), \mathrm{CaCl}_{2}$ (0.01), $\mathrm{Na}_{2} \mathrm{HPO}_{4}(0.5)$, yeast extract (0.05), agar (15) and $0.001 \%$ of Tween 80 and $1 \%$ of olive oil. After isolation, BF-6 was maintained in DYG'S medium at $\mathrm{pH} 6.0$ containing $(\mathrm{g} / \mathrm{L})$ : glucose $(2)$, bacteriological peptone (1.5), yeast extract (2), $\mathrm{K}_{2} \mathrm{HPO}_{4}(0.5)$ and $\mathrm{MgSO}_{4}(0.5)$ and $40 \%$ glycerol. The strain was preserved at $-80{ }^{\circ} \mathrm{C}$ in glycerol.

\section{Identification of isolated strain}

BF-6 was identified by 16S rRNA gene sequencing. The genomic DNA was extracted using System AxyPrep ${ }^{\mathrm{TM}}$ Bacterial Genomic DNA Miniprep Kit (Axygen Biosciences) according to manufacturer instructions. Genes for $16 \mathrm{~S}$ rRNA was amplified using specific primers (fD1 AGAGTTTGATCCTGGCTCAG) and (rD1 AAGGAGGTGATCCAGCC). ${ }^{(9)}$ The reaction was performed in a PTC 200 thermocycler (J Research Inc.), using an initial cycle of denaturation at $95{ }^{\circ} \mathrm{C}$ for $2 \mathrm{~min} ; 30$ cycles at $94{ }^{\circ} \mathrm{C}$ for $15 \mathrm{sec}$ (denaturation), $93{ }^{\circ} \mathrm{C}$ for $45 \mathrm{sec}$ (denaturation), $55{ }^{\circ} \mathrm{C}$ for $45 \mathrm{sec}$ (annealing), $72{ }^{\circ} \mathrm{C}$ for $2 \mathrm{~min}$ (extension); and a final extension at $72{ }^{\circ} \mathrm{C}$ for $5 \mathrm{~min}$. In order to obtain the sequence for $16 \mathrm{~S}$ rRNA, the PCR products were submitted to five PCR reactions using primers FD1, ${ }^{(9)} \mathrm{Y} 2$ (CCCACTGCTGCCTCCCGTAGGAGT), ${ }^{(10)} 362 \mathrm{f}$ (- CTCCTACGGGAGGCAGCAGTGGGG), 786f (- CGAAAGCGTGGGGAGCAAACAGG) and 1203f (1179-1203 - GAGGTGGGGATGA CGTCAAGTCCTC). ${ }^{(11)}$ All reactions were performed using the following program: initial denaturation at $95{ }^{\circ} \mathrm{C}$ for $2 \mathrm{~min} ; 30$ cycles at $95{ }^{\circ} \mathrm{C}$ for $10 \mathrm{sec}$ (denaturation), $50{ }^{\circ} \mathrm{C}$ for $4 \mathrm{sec}$ (annealing); $60^{\circ} \mathrm{C}$ for $4 \mathrm{~min}$ (extension), and final cooling to $4{ }^{\circ} \mathrm{C}$. The PCR products were purified, sequenced, and aligned. ${ }^{(11)}$ The identification of the isolates was performed by aligning the gene for the 16S rRNA of isolate with sequences deposited in GenBank (http://www.ncbi.nlm.nih.gov/blast), considering the highest identity obtained. The phylogenetic tree was generated using NeighborJoining tree method and the numbers at nodes show the bootstrap values obtained with 1000 resampling analyses. Escherichia coli K-12 sequence was used as outgroup. Phylogenetic and molecular evolutionary analyses were conducted using MEGA version 4.

\section{Carbon alternative sources}

Chicken fat (CF) was donated by Big Frango slaughterhouse located in Rolândia, PR, Brazil and consists of a byproduct of industrialization of chicken meat. Soybean gum (SG) and crude lecithin gum (CLG) were donated by Cocamar located in Londrina, PR, and are byproducts of soybean oil refining process.

\section{Submerged fermentation}

The strain BF- 6 was grown in $125 \mathrm{ml}$ flasks containing $30 \mathrm{ml}$ of minimum medium containing (g/L): $\mathrm{NaNO}_{3}(4.0), \mathrm{KH}_{2} \mathrm{PO}_{4}(1.5), \mathrm{FeCl}_{3}(0.05)$,

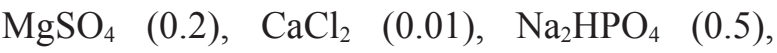
yeast extract $(0.05)$ and $1 \%$ of $\mathrm{CF}, \mathrm{SG}$, or $\mathrm{CLG}$ $(w / v)$. Olive oil was used as a control at the same concentration. The inoculum containing $0.2 \mathrm{~g} / \mathrm{L}$ of cells was used in all fermentations. The flasks were incubated at $28{ }^{\circ} \mathrm{C}, 200 \mathrm{rpm}$ for 96 hours. Samples $(2 \mathrm{ml})$ were removed at 24 hours intervals. To evaluate the effect of CLG concentration on lipase production, the strain was cultured at the same conditions for 24 hours in minimum medium containing different concentrations of CLG $(0.5 \%$ to $5.0 \%(\mathrm{w} / \mathrm{v}))$. The fermentations were interrupted by centrifugation at $9056 \times \mathrm{g}$ for 10 minutes, at $4{ }^{\circ} \mathrm{C}$. Supernatant was used for assay of lipase activity and the precipitate was used for determination of biomass.

\section{Effect of temperature and $\mathrm{pH}$}

on lipase production

To verify the optimum temperature for lipase production, the strain was cultured in minimum medium containing $2 \%$ of CLG (w/v) and incubated at different temperatures $\left(25^{\circ} \mathrm{C}\right.$, 
$30{ }^{\circ} \mathrm{C}, 35^{\circ} \mathrm{C}$ and $45^{\circ} \mathrm{C}$ ) at $200 \mathrm{rpm}$ for 24 hours. For investigated the optimum $\mathrm{pH}$ the strain was cultured in minimum medium added to $2 \%$ of CLG (w/v) at different $\mathrm{pH}(3,4,5,6,7,8$, and 9$)$ at $200 \mathrm{rpm}, 35^{\circ} \mathrm{C}$ for 24 hours. Fermentations were interrupted by centrifugation at $9056 \times \mathrm{g}$ for 10 $\mathrm{min}$, at $4{ }^{\circ} \mathrm{C}$. The supernatant was used for assay of lipase activity and the precipitate was used for determination of biomass.

\section{Determination of lipase activity and biomass}

The lipase activity was assayed using p-nitrophenyl-palmitate (pNPP) as substrate..$^{(12)}$ The cell-free supernatant was incubated with pNPP (8.0 mM dissolved in isopropanol), 50 $\mathrm{mM}$ Tris- $\mathrm{HCl}$ buffer $(\mathrm{pH} 8.5)$ containing Triton $\mathrm{X}-100(0.4 \% \mathrm{w} / \mathrm{v})$, at $37{ }^{\circ} \mathrm{C}$, for 10 minutes. The release of pNPP was measured at $410 \mathrm{~nm}$. One unit of enzyme activity $(\mathrm{U} / \mathrm{ml})$ was defined as the amount of enzyme required to release $1 \mu \mathrm{mol} /$ min of p-NPP. The biomass was determined by spectrophotometry at $620 \mathrm{~nm}$, according to previously determined calibration curve.

\section{Determination of optimal $\mathrm{pH}$ and temperature of crude lipase}

The optimum temperature for the lipase was determined by incubating the enzyme with the substrate (p-NPP) at temperatures ranging from 25 to $75{ }^{\circ} \mathrm{C}$, in $50 \mathrm{mM}$ Tris buffer, $\mathrm{pH} 8.5$ for 10 minutes. The thermal stability was studied by incubating the enzyme at each desired temperature for 2 hours. The optimum $\mathrm{pH}$ for the crude lipase was determinate by incubating the enzyme with $\mathrm{p}$-NPP at various $\mathrm{pH}$ ranging from 3.0 to 9.0 at optimized temperature value in the following buffers: $50 \mathrm{mM}$ citrate phosphate buffer $(\mathrm{pH}$ 3.0-6.0), $50 \mathrm{mM}$ Tris buffer ( $\mathrm{pH} 7.0-9.0$ ), for 10 minutes. The $\mathrm{pH}$ stability was studied by incubating the lipase at each desired $\mathrm{pH}$, and then measuring the lipase activity after 2 hours. ${ }^{(12)}$

\section{Effect of surfactants and organic solvents} on crude lipase activity

The stimulatory or inhibitory effect of organic solvents and detergents on the enzyme activity was carried out by the addition of $10 \%$ (v/v) of isopropanol, ethanol, acetonitrile, acetone, hexane, Tween 80 and Triton X-100 on the enzyme solution, for 2 hours, at $30^{\circ} \mathrm{C}$. After incubation, the residual activity of the enzyme was measuring. ${ }^{(12)}$

\section{Results and Discussion}

\section{Identification of bacteria strain}

The 16S rDNA sequence of the isolate was blasted using megablast tool of GenBank (http://www.ncbi.nlm.nih.gov/). This revealed that this isolate belongs to a Pseudomonas genus. Representative of maximum homologous sequences were used for the construction of phylogenetic affiliation (Figure 1). The nucleotide sequence reported here has been assigned an accession number GI824991972 from NCBI Gene Bank database. Pseudomonas is a genus of gram-negative, aerobic gamma proteobacteria, belonging to the family Pseudomonadaceae containing 191 validly described species. The members of the genus demonstrate a great deal of metabolic diversity, and consequently are able to colonize a wide range of niches. 
Figure 1 - Phylogenetic tree based on 16S rRNA sequences of Pseudomonas sp. BF and other lipase produced by Pseudomonas. Tree was generated using Neighbor-Joining tree method and the numbers at nodes show the bootstrap values obtained with 1000 resampling analyses. Escherichia coli K-12 sequence was used as outgroup. Phylogenetic and molecular evolutionary analyses were conducted using MEGA version 4.

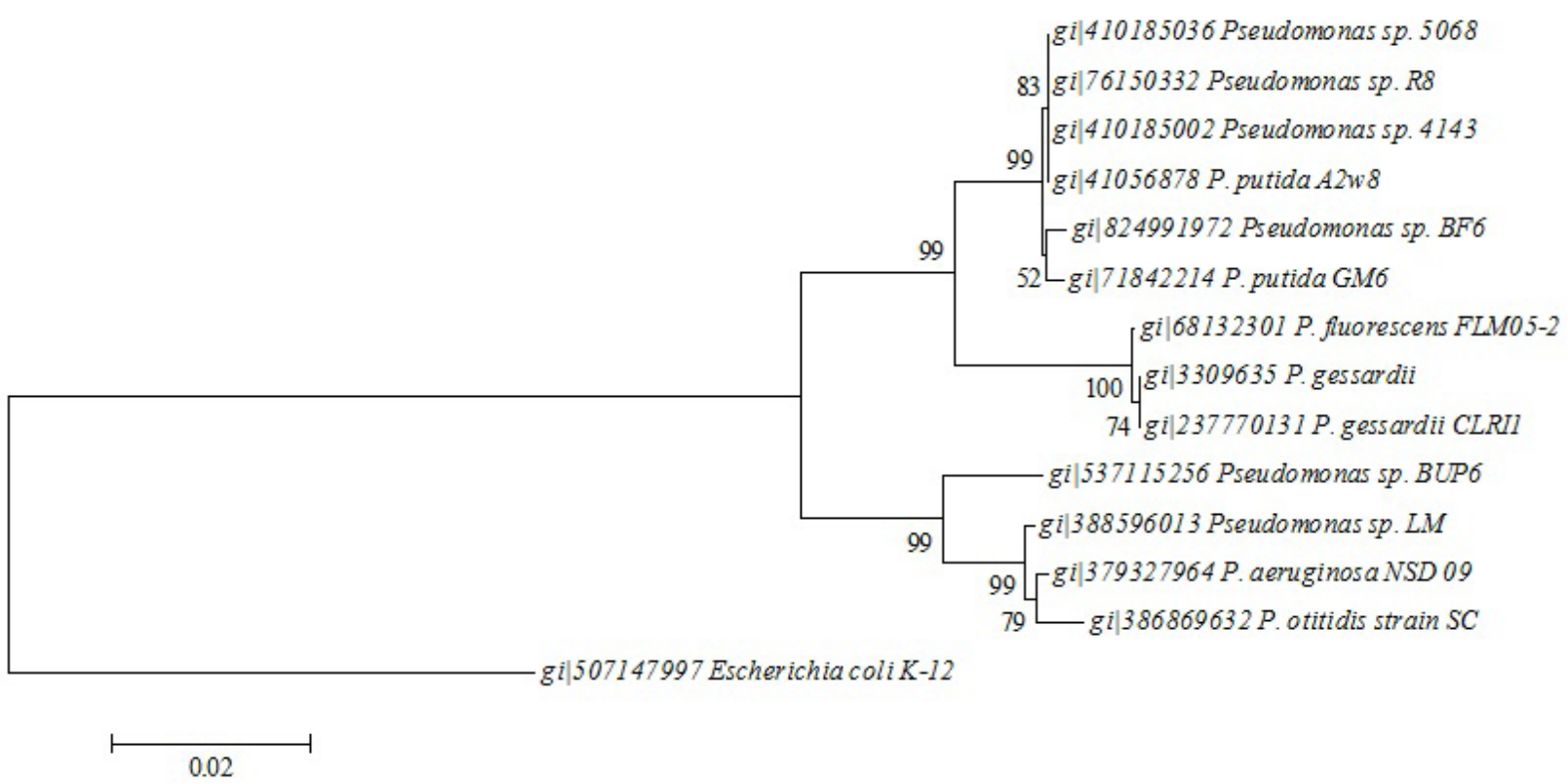

Font: Authors

Optimization of lipase production by Pseudomonas sp.

The lipase production by Pseudomonas sp. was assessed by submerged fermentation, which is the commonly used method for lipase production in large scale. ${ }^{(1-3)}$ Initially, the strain was cultured in medium containing olive oil as carbon source. According to the results, the higher lipase production was observed after 24 hours of culture (35 U/ml). After 72 hours, a drastic drop of the enzyme production was detected $(6.1 \mathrm{U} / \mathrm{ml})$. Similar results were obtained by other authors ${ }^{(13)}$ which showed greater lipase production by Pseudomonas aeruginosa after 28 hours of incubation. On the other hand, Ruchi and coworkers ${ }^{(14)}$ reported higher lipase production by Pseudomonas aeruginosa after 48 hours of incubation. The greatest biomass values were detected in 48 hours of fermentation $(11.6 \mathrm{mg} / \mathrm{ml})$ (Figure 2). According to the literature, bacteria belonging to the genus Pseudomonas produce different types of lipases, in submerged or solid-state fermentation ${ }^{(14)}$. In addition, some authors have described the simultaneous production of lipases and proteases by Pseudomonas strain. ${ }^{(13)}$

Figure 2 - Biomass (A) and lipase activity (B) of Pseudomonas sp. cultivated for 96 hours in minimum medium containing $1 \%(\mathrm{w} / \mathrm{v})$ of chicken fat (CF), soybean gum (SG), crude lecithin gum (CLG) or olive oil (OL) at $28{ }^{\circ} \mathrm{C}, 200 \mathrm{rpm}$. All measurements are the mean of three experimental data.

\section{A}

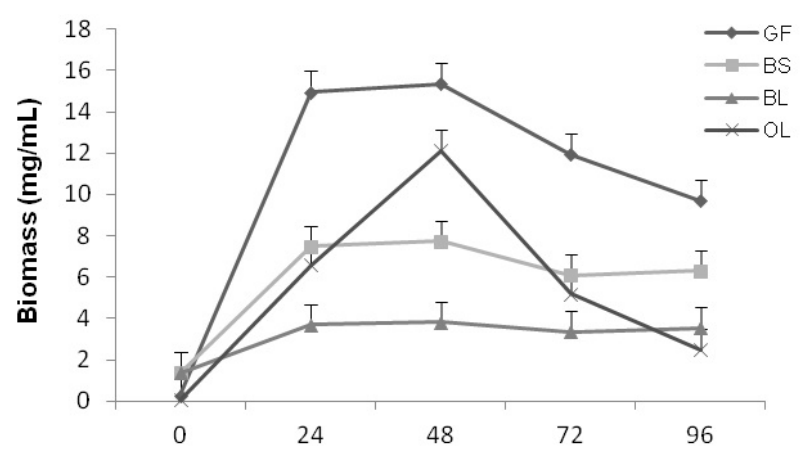

Continues 


\section{Continuation}

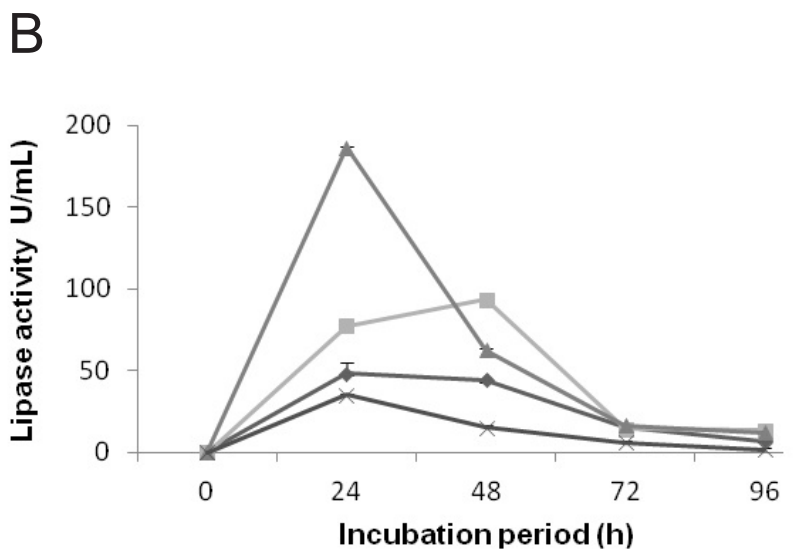

Font: Authors

Aiming to increase the lipase production, some alternatives sources of carbon were tested. The results showed that all tested substrates were able to induce lipase production. Interestingly, the CF was capable to induce significant amount of biomass reached $14.96 \mathrm{mg} / \mathrm{ml}$ after 24 hours (Figure 2A). The biomass remained constant after 48 hours and a decrease was observed after 72 hours. The lipase activity reached its maximum after 24 hours (48.3/ $\mathrm{ml}$ ) and showed a decrease after 48 hours of culture (Figure 2B). These results suggest that CF can be used for lipase production by Pseudomonas sp. In recent years, the production of poultry meat has increased significantly, generating large amounts of industrial waste from the processing of poultry.
These agroindustrial wastes are rich in lipids and can be used in various products, but are frequently used in products with low added-value. ${ }^{(15)}$

The main byproduct of soybean oil refining industry, SG, was also evaluated as a possible source of carbon for the production of lipase by Pseudomonas sp. The results showed that the cultivation of Pseudomonas sp. in medium containing SG biomass reached values of around 6-7 $\mathrm{mg} / \mathrm{ml}$ in all tested time intervals (Figure 2A). The lipase activity was higher after 48 hours, reaching 93.3/mL (Figure 2B).

Soybean oil refining process also generates CLG, which contains approximately $50 \%$ of phospholipids and $25 \%$ of oil. The culture of Pseudomonas sp. in CLG resulting in lower values of biomass (about 3-4 mg/mL), when compared to other byproducts. However, the CLG resulted in the higher lipase activity when compared to $\mathrm{CF}$ and $\mathrm{SG}$, reaching about $186.220 \mathrm{U} / \mathrm{ml}$ of lipase activity after 24 hours of incubation (Figure 2B). Soybean lecithin have been used in the human diet since they improve the nutritional status of diets by emulsification of fats, allowing an increase in digestion and absorption of fats. Lecithin has other important functions, such as antioxidants and has been shown to be a natural antioxidant for use in pigs and poultry food. ${ }^{(16)}$ In addition, the results presented in this study suggest that the CLG can be used as carbon source for the lipase production inducing high enzyme activity.

Figure 3 - Biomass and lipase activity of Pseudomonas sp. cultured $\left(28^{\circ} \mathrm{C}, 200 \mathrm{rpm}\right.$, 24 hours) on minimal medium containing different concentrations of CLG. All measurements are the mean of three experimental data.

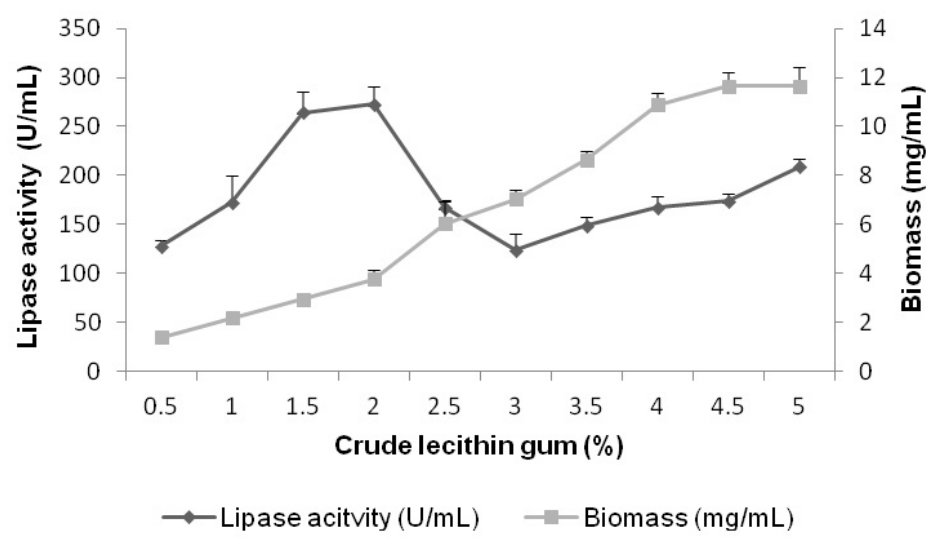

Font: Authors 
The next step was to evaluate the optimal concentration of CLG for the production of lipases by Pseudomonas sp. The results indicated that concentrations between $1.5 \%$ and $2.0 \%$ of CLG produced the highest enzymatic activity, reaching 264.2 U/ml and 272.6 U/ml, respectively (Figure 3 ). The biomass values increased in proportion to the concentration of CLG in the culture medium. The optimization of temperature and $\mathrm{pH}$ to lipase production was performed in medium containing $2.0 \%$ of BL after 24 hours of cultivation. The results showed values of biomass around $7.0 \mathrm{mg} / \mathrm{mL}$ in all tested temperatures. The lipolytic activity was higher in $30^{\circ} \mathrm{C}$, reaching $408.7 \mathrm{U} / \mathrm{ml}$ of enzymatic activity. A decrease in lipase activity was observed at temperatures above $35^{\circ} \mathrm{C}$ (Figure 4). Using a temperature of $30{ }^{\circ} \mathrm{C}$, the microorganism also was able to grow in a wide $\mathrm{pH}$ range (Figure 5). A good lipase production was observed in all tested $\mathrm{pH}$ values, with more production at $\mathrm{pH} 6.0$
$(812.7 \mathrm{mg} / \mathrm{mL})$. The results obtained in this study are in agreement with the literature that shows that lipases from Pseudomonas are more active in temperature between $30{ }^{\circ} \mathrm{C}$ and $40{ }^{\circ} \mathrm{C}$. ${ }^{(17)} \mathrm{On}$ the other hand, these authors observed the highest enzyme production in $\mathrm{pH}$ around 9.

In the previous study it was showed that the dairy effluent constitute a useful medium for lipase production by Trichoderma atroviride 676 , contributing to reduce the fermentation cost and helping to minimize environmental problems caused by dairy industry. ${ }^{(18)}$ Ramani and coworkers $^{(19)}$ also showed the production of lipase by Pseudomonas gessardii using beef tallow as a substrate. Furthermore, Salihu and coworkers ${ }^{(20)}$ reported the production of lipase by Candida cylindracea using effluent oil obtained in refining industry. Asih and colleagues ${ }^{(21)}$ reported the production of lipase by Candida cylindracea using palm oil mill effluente.

Figure 4 - Lipase activity and biomass of Pseudomonas sp. cultured on minimal medium containing $2 \%$ of CLG incubated in different temperatures $\left(25^{\circ} \mathrm{C}, 30{ }^{\circ} \mathrm{C}, 35^{\circ} \mathrm{C}\right.$, $40{ }^{\circ} \mathrm{C}$ and $45^{\circ} \mathrm{C}$ ) at $200 \mathrm{rpm}$ for 24 hours. The assays were performed in triplicate.

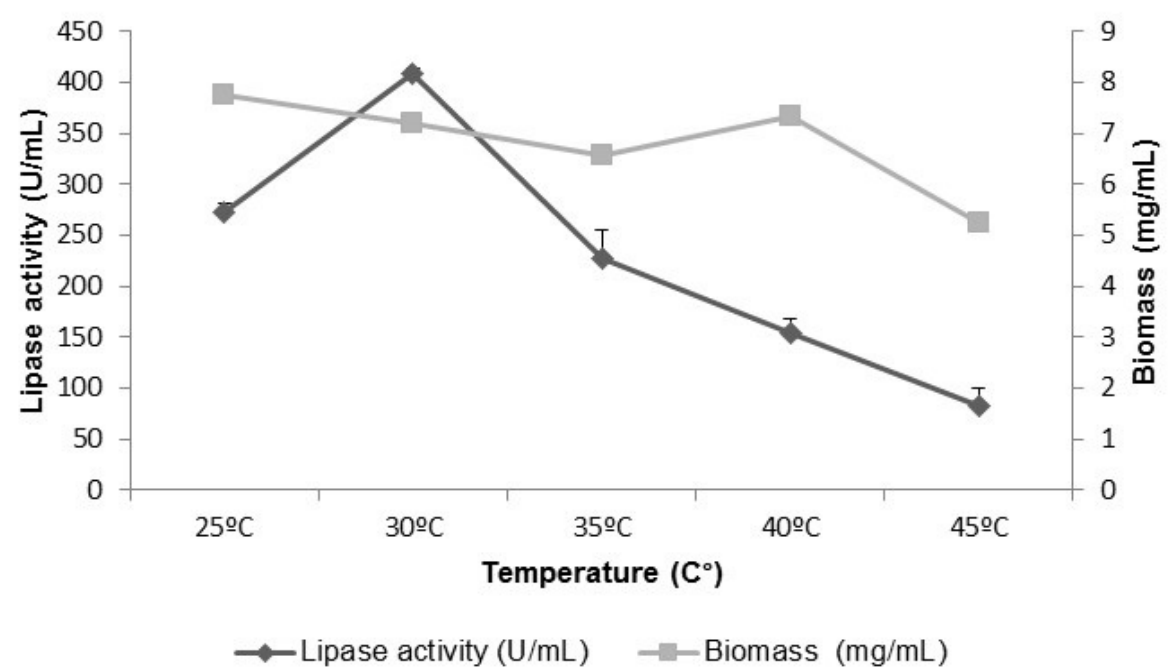

Font: Authors

\section{Partial biochemical characterization of crude lipase}

The crude lipase was active in the range of temperature from 25 to $75{ }^{\circ} \mathrm{C}$ with higher activity at $35{ }^{\circ} \mathrm{C}$. The thermo stability assay showed that the lipase from Pseudomonas sp. retained stable at all tested temperature, showing a mild decrease at $65{ }^{\circ} \mathrm{C}$ and $75^{\circ} \mathrm{C}$ (Figure 6A). Lipases from other strains of Pseudomonas such as P. fluorescens 2D, HU380 P. fluorescens, P. fragi and P. mendoncina were also more active in the temperature range 
between $35{ }^{\circ} \mathrm{C}$ and $45{ }^{\circ} \mathrm{C} .{ }^{(22,23)}$ The maximum relative activity of lipase was observed at pH 9.0. However, the sample also showed higher activity at $\mathrm{pH} 6$ suggesting that more than one lipase in the enzyme extract. Dandavate and coworkers ${ }^{(24)}$ described an alkaline lipase from Burkholderia multivorans with maximum activity at $\mathrm{pH} 8$. Similar results were obtained for the stability test after 2 hours of incubation (Figure 6B). At $\mathrm{pH} 4$ and 5 the crude lipase showed absence of/or very low enzymatic activity (Figure 6B).
The effect of different organic solvents on lipase stability is shown in Figure 6C. All organic solvents have moderate inhibitory effect when compared to the control. However, the enzyme showed good stability in organic solvents such as acetronitrile hexane, ethanol and isopropanol. Total lack of residual activity was observed in the presence of detergent Triton X -100 and Tween 20. Dandavate and coworkers ${ }^{(24)}$ also described the characterization of organic solvent tolerant lipase isolated from Bukholderia multivoran.

Figure 5 - Lipase activity and biomass of Pseudomonas sp. cultured on minimal medium containing $2 \%$ of CLG in initial different $\mathrm{pH}(3,4,5,6,7,8$ and 9$)$ at $200 \mathrm{rpm}, 35^{\circ} \mathrm{C}$ for 24 hours. All measurements are the mean of three experimental data.

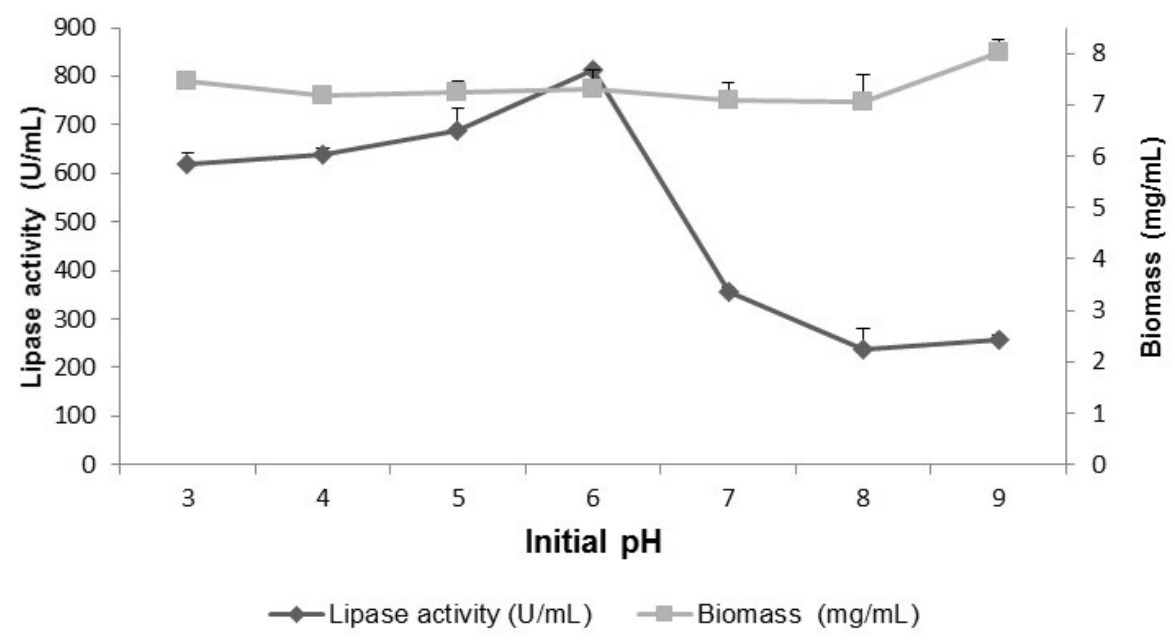

Font: Authors

Figure 6 - Activity (10 minutes of incubation) and stability (2 hours of incubation) of lipase at different temperatures (A) and $\mathrm{pH}(\mathrm{B})$. Effect of organic solvents and surfactants on lipase activity was also evaluated (C). Lipase activity in the absence of organic solvents and surfactants (control) was considered as $100 \%$. The experiments were performed in duplicate. The values represent the average of two independent experiments.

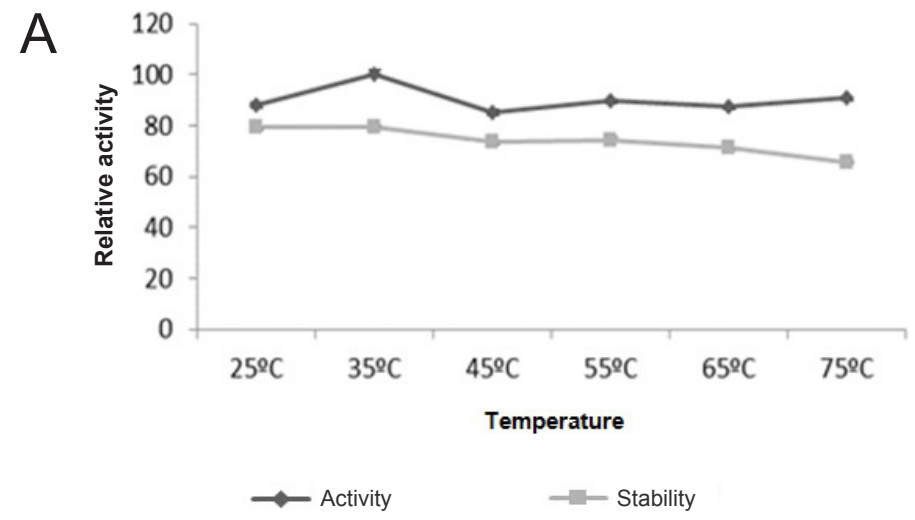




\section{Continuation}
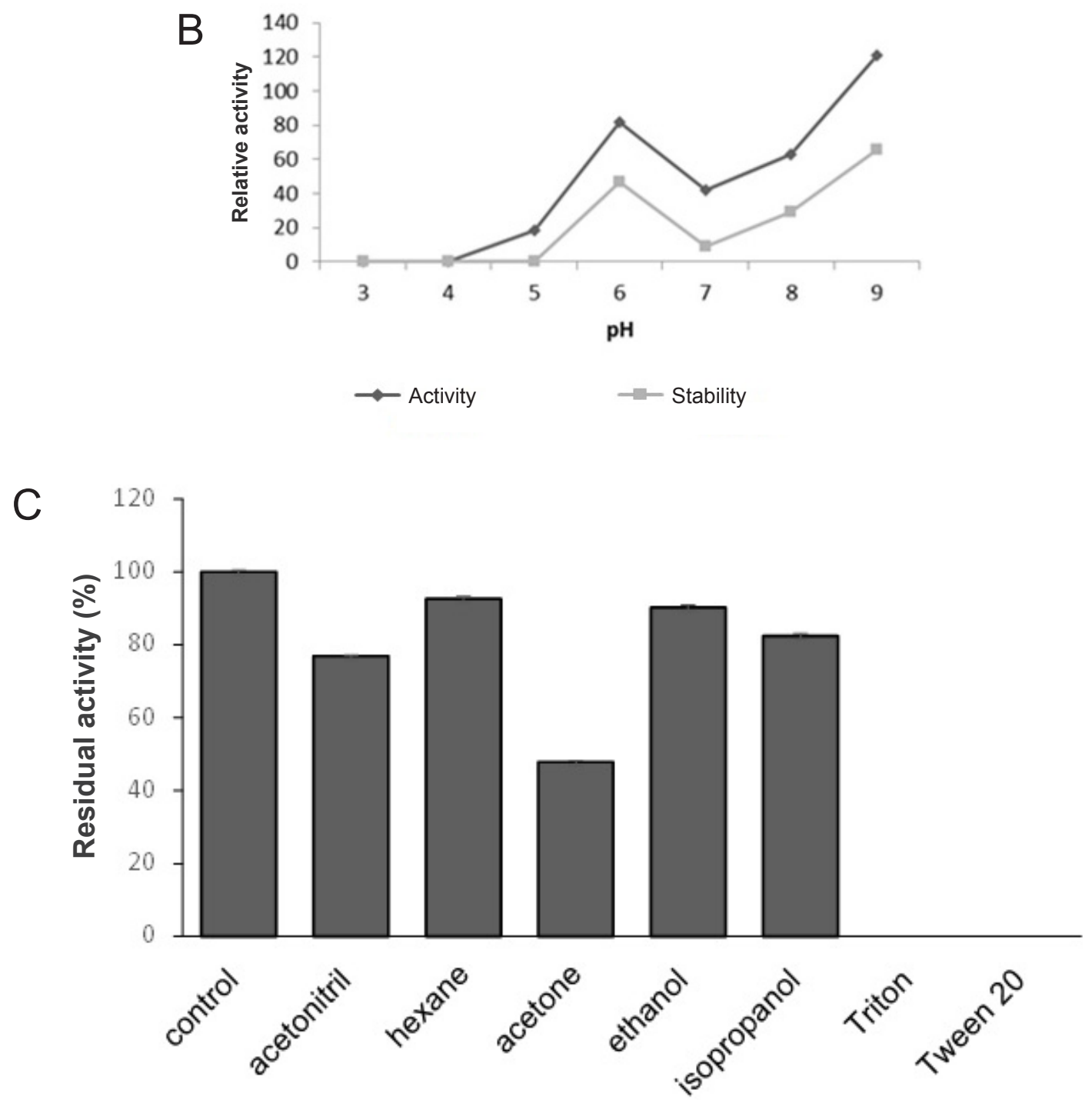

Font: Authors

\section{Conclusions}

The results showed the possibility of using the CLG as substrate for lipase production by Pseudomonas sp. and can contribute in the reduction of production cost of lipases in industrial scale, and increase the market value of soybean oil byproducts. To our knowledge, this is the first study on the optimization of lipase production from Pseudomonas sp. using CLG based medium. In addition, lipase from Pseudomonas sp. is stable in a wide range of temperatures and $\mathrm{pH}$ and has good stability in organic solvents. Active and stable in alkaline lipases are industrially very attractive and have great potential for application in the detergent industry. Furthermore, it can be used for biodiesel synthesis, biopolymers and production of pharmaceuticals, agrochemicals and fragrances and cosmetics.

\section{Acknowledgements}

The authors thanks to Coordenação de Aperfeiçoamento de Pessoal de Nível Superior (CAPES/PNPD) and Fundação Araucária, Brazil for financial support. 


\section{References}

1 Patel N, Rai D, Shivam, Shahane S, Mishra U. Lipases: Sources, Production, Purification, and Applications. Recent Pat Biotechnol. 2018;12:1-12. doi: 10.2174/187220831266618 1029093333.

2 Rodrigues RC, Virgen-Ortíz JJ, Dos Santos JCS, Berenguer-Murcia Á, Alcantara AR, Barbosa O, Ortiz C, Fernandez-Lafuente R. Immobilization of lipases on hydrophobic supports: mmobilization mechanism, advantages, problems, and solutions. Biotechnol Adv. 2019;37(5):746-70. doi: 10.1016/j. biotechadv.2019.04.003.

3 Shuai W, Das RK, Naghdi M, Brar SK, Verma M. A review on the important aspects of lipase immobilization on nanomaterials. Biotechnol Appl Biochem. 2017;64(4):496-508. doi: 10.1002/bab.1515.

4 Villeneuve P, Muderhwa JM, Graille J, Haas, MJ. Customizing lipases for biocatalysis: a survey of chemical, physical and molecular biological approaches. J Mol Catal B-Enzym. 2000;9(4-6):113-48. doi: 10.1016/S13811177(99)00107-1.

5 Barros M, Fleuri LF, Macedo GA. Seed Lipase: sources, applications and properties a review. Braz J Chem Eng. 2010;27(1):15-29. doi: 0.1590/S0104-66322010000100002.

6 Choudhury P, Bhunia B. Industrial application of lipase: a review. Biopharm J. 2015; 1(2): 41-7.

7 Treichel H, Oliveira D, Mazutti MA, Di Luccio M, Oliveira JV. A review on microbial lipases production. Food Bioproc Tech. 2010;3(2):18296. doi: 0.1007/s11947-009-0202-2.

8 Smaniotto A, Skovronski A, Rigo E, Tsai SM, Durrer A, Foltran LL, Treichel H. Concentration, characterization and application of lipases from Sporidiobolus pararoseus strain. Braz J Microbiol. 2014;45(1);294-302. doi: 10.1590/ S1517-83822014000100043 .

9 Weisburg WG. Barns SM, Pelletier DA, Lane, DJ. 16S ribosomal DNA amplification for phylogeneticstudy.JBacteriol.1991;173(2):697703. doi: 10.1128/jb.173.2.697-703.1991.
10 Young JP, Downer HL, Eardly BD. Phylogeny of the phototrophic rhizobium strain BTAi1 by polymerase chain reaction-based sequencing of a $16 \mathrm{~S}$ rRNA gene segment. J Bacteriol. 1991;173(7): 2271-7. doi: 10.1128/ jb.173.7.2271-2277.1991.

11 Menna P, Hungria $\mathrm{M}$, Barcellos FG, Bangel EV, Hess PN, Martínez-Romero E. Molecular phylogeny based on the $16 \mathrm{~S}$ rRNA gene of elite rhizobial strains used in Brazilian commercial inoculants. Syst Appl Microbiol. 2006;29(4):315-32. doi: 10.1016/j. syapm.2005.12.002.

12 Winkler UK, Stuckmann M. Glycogen, hyaluronate, and some other polysaccharides greatly enhance the formation of exolipase by Serratia marcescens. Journal of Bacteriology, 1979; 138(3):663-70. doi: 0021-9193/79/060663/08\$02.00/0.

13 Bisht D, Yadav SK, Gautam P, Darmwal NS. Simultaneous production of alcaline lipase and protease by antibiotic and heavy metal tolerant Pseudomonas aeroginosa. J Basic Microbiol. 2012;52:1-8. doi: 10.1002/ jobm.201200157.

14 Ruchi G, Anshu G, Khare SK. Lipase from solvent tolerant Pseudomonas aeruginosa strain: Production optimization by response surfacemethodologyandapplication. Bioresour Technol. 2008;99(11):4796-802. https://doi. org/10.1016/j.biortech.2007.09.053

15 Centenaro, GS, Furlan VJM, SouzaSoares LA. Gordura de frango: alternativas tecnológicas e nutricionais. Semina Ciênc Agrár. 2008;29(3):619-30.

16 Said NW. Extrusion of alternative feed ingredients: An environmental and nutritional solution. J Appl Poult Res. 1996;5:395-407.

17 Kiran GS, Shanmughapriya S, Jayalakshmi J, Selvin J, Gandhimathi, R., Sivaramakrishnan $\mathrm{S}$, et al. Optimization of extracellular psychrophilic alkaline lipase produced by marine Pseudomonas sp. (MSI057). Bioproc Biosyst Eng. 2008;31(5):483-92. doi: 10.1007/ s00449-007-0186-0. 
18 Marques TA, Baldo C, Borsato D, Buzato JB, Celligoi MAPC. Utilization of dairy effluent as alternative fermentation medium for microbial lipase production. Rom Biotechnol Lett. 2014;19(1):9042-50.

19 Ramani A, Kennedy LJ, Ramakrishnan M, Sekaran G. Purification, characterization and application of acidic lipase from Pseudomonas gessardii using beef tallow as a substrate for fats and oil hydrolysis. Process Biochem. 2010;45(10),1683-91. doi: 10.1016/j. procbio.2010.06.023.

20 Salihu A, Alam MZ, Abdulkarim MI, Salleh HM. Optimization of lipase production by Candida cylindracea in palm oil mill effluent based medium using statistical experimental design. J Mol Catal B-Enzym. 2011;69(12):66-73. doi: 10.1016/j.molcatb.2010.12.012.

21 Asih DR, Alam MZ, Salleh MN, Salihu A. Pilot-scale production of lipase using palm oil mill effluent as a basal medium and its immobilization by selected materials. J Oleo Sci. 2014;63(8):779-85. doi: 10.5650/jos. ess13187.

22 Jinwal U, Roy U, Chowdhury A, Bhaduri A, Roy PK. Purification and characterization of an alkaline lipase from a newly isolated Pseudomonas mendoncina PK-12Cs and chemoselective hydrolysis of fatty acid ester. Bioorg Med Chem. 2003;11(6):1041-1046. doi: 10.1016/S0968-0896(02)00516-3.

23 Karadzic I, Masui A, Zivkovic LI, Fujiwara N. Purification and characterization of an alkaline lipase from Pseudomonas aeruginosa isolated from putrid mineral cutting oil as component of metalworking fluid. J. Biosci Bioeng. 2006;102: 82-9. doi: 10.1263/jbb.102.82.

24 Dandavate V, Jinjala J, Keharia H, Madamwar D. Production, partial purification and characterization of organic solvente tolerant lipase from Burkholderia multivorans V2 and its application for ester synthesis, Bioresour Technol. 2009;100(13):3374-81. doi: 10.1016/j.biortech.2009.02.01. 
Baldo, C. et al. 